\title{
Seasonal Changes in Time Spent Grazing and Resting of Misaki Horses
}

Yujiro KASEDA

Faculty of Agriculture, Miyazaki University, Miyazaki-shi 880

\author{
(Received December 15, 1982)
}

\begin{abstract}
Investigations were made on the seasonal changes in the diurnal patterns of activities and time spent grazing and resting of Misaki horses living under a wild-like condition in order to analyze their behavioral adaptation to their environment. Fifty-five continuous observations ranging from 2 to 24 hours were made on the behavior of 12 adult horses during the period from June, 1979 to August, 1982. Almost all horses grazed predominantly around dusk, in midnight and soon before dawn in summer. In winter they usually began to graze near dawn and spent more grazing time and less resting time during warm daylight hours and spent more resting time at cold night. Total time spent grazing and time spent grazing at night were longer in summer than in winter. On the other hand, total time spent resting and time spent resting at night were longer in winter than in summer, although food available was poor in quality and quantity in winter. It is suggested that these seasonal changes in behavioral patterns might result in reduction in energy expenditure due to grazing or brawsing and in conservation of body energy in winter.
\end{abstract}

Jpn. J. Zootech. Sci., 54 (7): 461-469, 1983

Animals may achieve behavioral adaptation by avoiding stressors, by changes in posture and motor activities and by changes in food and water intake and selection ${ }^{1}$. When food is poor on either rangeland or pasture, the animals grazing there will spend more grazing time, because the amount of food consumed is determined by the animal's rate of eating coupled with the time spent grazing ${ }^{2}$. When the daytime temperature exceeds the comfortable zone, animals tend to increase their night grazing ${ }^{1)}$. TyLER has reported that New Forest Ponies had few of resting bouts during daylight hours and devoted the whole day to grazing and brawsing in winter ${ }^{3}$. In summer, animals are able to spend more resting time and increase the length of resting bouts with an increase in food available ${ }^{3)}$ and tend to become nocturnal during hot weather ${ }^{1.4}$. In winter, on the other hand, animals subject to preiods of energydraining cold stress and in addition, must expend much energy in seaching for and harvesting food under the condition of sparse food available ${ }^{5}$. Animals, therefore, usually adjust their grazing behavior to consume more food, by increase in time spent grazing and decrease in time spent resting ${ }^{1,2}$.

The present study was carried out to analyze the behavioral adaptation of Misaki horses living under a wild-like condition, by investigating seasonal changes in daily activities and time spent grazing and resting in relation to vegetation conditions and ambient temperature. 


\section{Materials and Methods}

The area is located in Ōgiyama area of Misaki pasture in Toi Cape of Miyazaki prefecture, in which 30 Misaki horses (the Japanese native horses) live under a wildlike condition without supplemental food by man all the year round. The grasslands are restricted to the area above the half way up Ōgiyama hill $(295 \mathrm{~m}$ above the sealevel) and are covered with many kinds of native grasses and forbs. Other areas are occupied by artificial forests with Japanese cedars and a variety of copses.

Fifty-five continuous observations ranging from 2 to 24 hours were carried out during the period from June, 1979 to August, 1982. Daily activities of 12 horses, consisting of 6 adult mares, 3 adult geldings and 3 young males older than 4 years, were individually recorded to investigate the diurnal patterns of activities and time spent grazing, resting and in other activities such as walking, suckling, urinating, drinking and defecating. Ambient temperature was measured at intervals of 20 to 30 min within a few meters from the horses observed. Conditions of food available were observed visually from the view point of their species, quality and quantity throughout the observations of behavior. Observations at night were aided by spotlights.

\section{Results and Discussion}

1. Diurnal patterns of grazing activity in summer and winter:

Horses usually spent most of their time on the grasslands in which native grasses and forbs were rich in quality and quantity during the summer season, but they tended to graze and rest in the forests or weedy grasslands during the winter season when grasses and forbs came to wither on the grasslands. Daily activities were divided into three categories; grazing, resting and other activities. The percentage of 24-h period spent in each activity in summer and winter is shown in Fig. 1. Almost all horses devoted most of a day to grazing and resting in either summer or winter, and

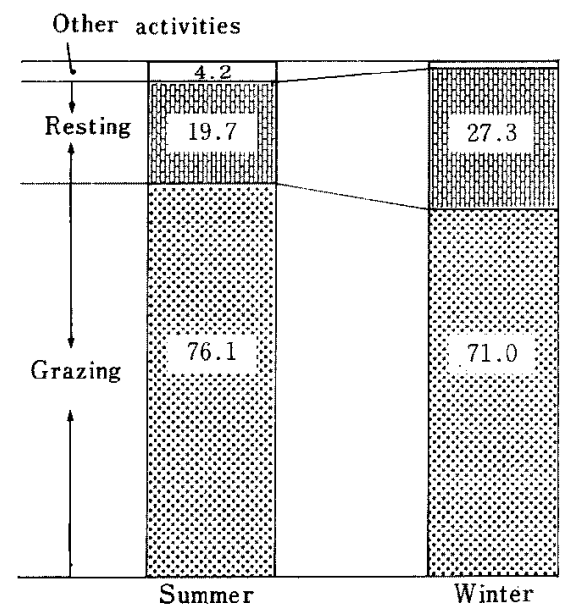

Fig. 1. Seasonal changes in the percentage of 24-h period spent in grazing, resting and other activities. 


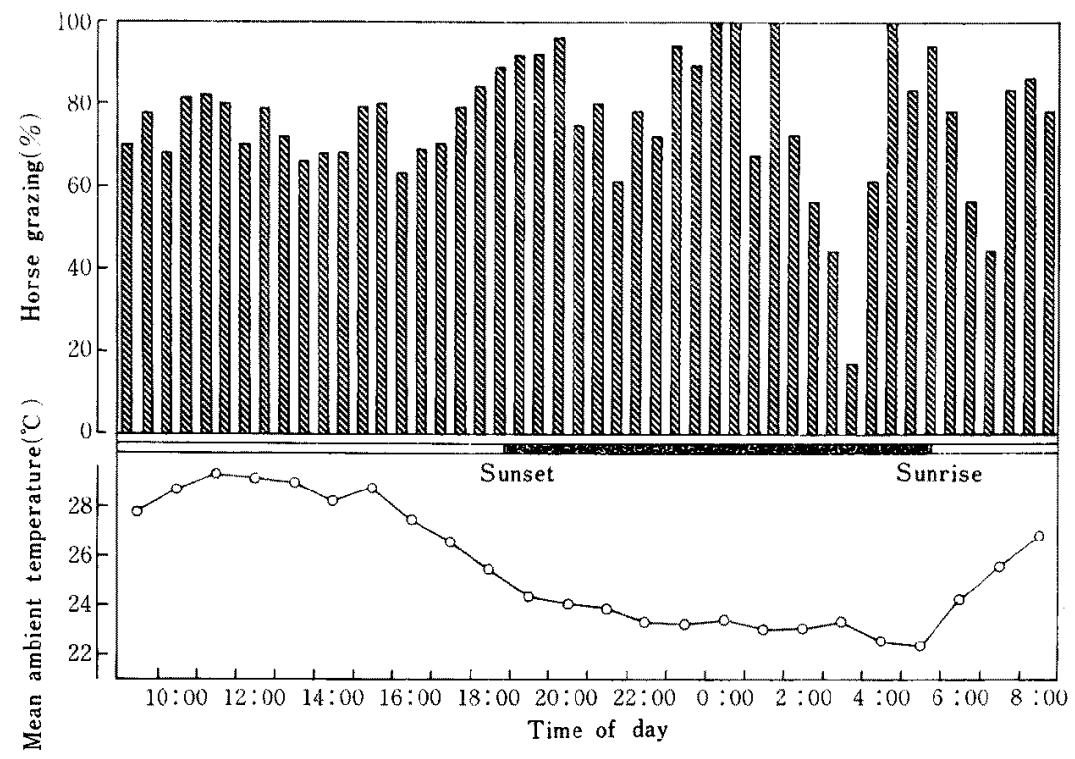

Fig. 2. Diurnal variation in the grazing intensity in summer. ${ }^{*}$ The grazing intensity was calculated as the percentage of horses grazing to the total number of horses observed at intervals of $30 \mathrm{~min}$.

other activities accounted for a small percentage. Harem stallions often took many hours to chase other males away from their groups not only in the breeding season but also in other season, but all horses observed in the present study usually passed their normal lives. Mean time spent grazing accounted for $76 \%$ and $71 \%$ of $24-\mathrm{h}$ period in summer and in winter, respectively (Fig. 1). Twenty-seven observations of behavior were made during the summer season (July, August and September) in 1979 to 1982 . Diurnal variation in the grazing intensity in summer is shown in Fig. 2, in which the grazing intensity was calculated as the percentage of horses grazing to the total number of horses observed at intervals of $30 \mathrm{~min}$. Grazing intensity during the hot daylight hours was found to be lower compared with that at night. Horses usually began to graze predominantly around dusk when the ambient temperature gradually declined, and continued to graze until midnight. After relatively long resting bouts, another peak of grazing was observed soon before dawn.

Diurnal variation of grazing activity in winter is shown in Fig. 3, in which the data were obtained from 16 observations during the winter season (December, January, February and March) in 1979 to 1982 . The diurnal pattern of grazing in winter showed different tendencies from that in summer. Most active grazings were found to concentrate before midday and in the late afternoon. After sunset, with a decrease in ambient temperature, almost all horses stopped grazing nearly simultaneously and spent long resting bouts until midnight. A relatively large peak of grazing activity was observed in midnight, but thereafter they spent again long resting time until dawn, while ambient temperature remained relatively low. 


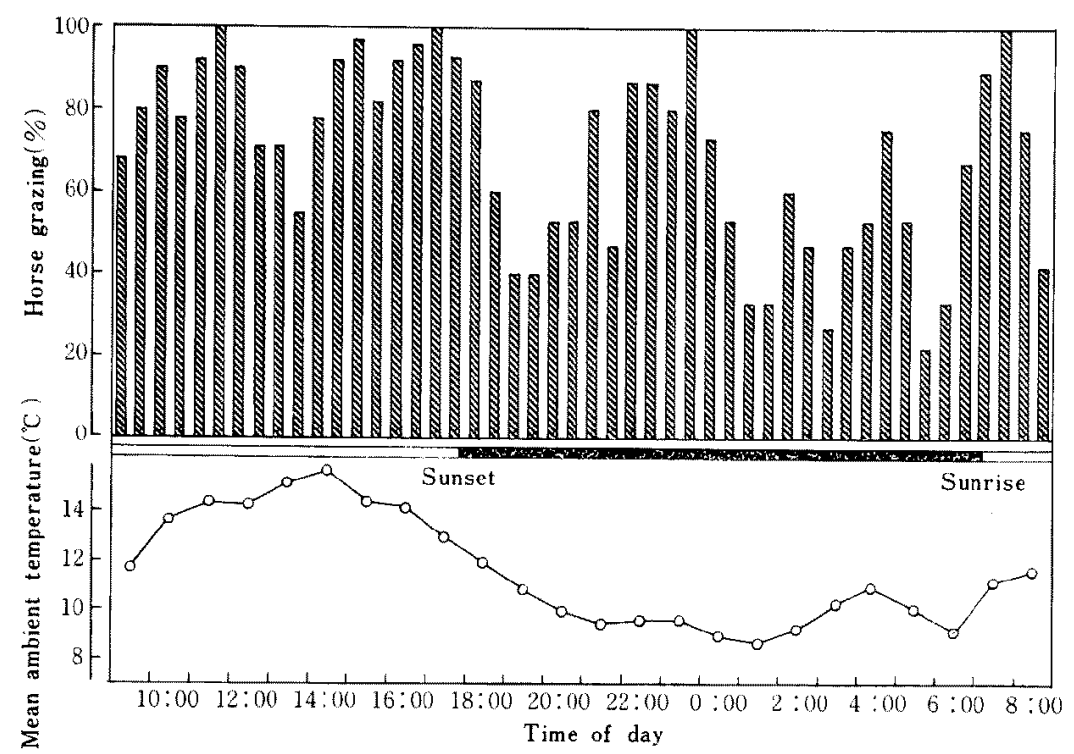

Fig. 3. Diurnal variation in the grazing intensity in winter. *The grazing intensity was calculated as the percentage of horses grazing to the total number of horses observed at intervals of $30 \mathrm{~min}$.

Many studies have shown that the most intensive grazing activities occurred in the morning and between late afternoon and evening ${ }^{1.2,6}$. Horses in the present study, however, did not such clear-cut diurnal patterns as reported for other farm animals. It is known that animals tend to reduce day grazing and increase night grazing in hot weather ${ }^{1.2,4,7)}$. Feral horses usually restricted their grazing to the cooler time of a day in the warmest months ${ }^{8}$. The daytime temperature on the grass. lands in the present study exceeded $25^{\circ} \mathrm{C}$ during the summer season. Almost all horses frequency spent resting bouts ranging from 20 to $60 \mathrm{~min}$ in the cool sites during the hot daylight hours and most active grazings occurred at night (Fig. 2). In the literature there is little informations regarding night activities in winter. TyLer has assumed for New Forest Ponies that most of the hours of darkness in all seasons were spent for grazing3), but ColLeRY has observed for feral horses that they lied down almost simultaneously as darkness approached in winter ${ }^{9)}$. In the present study, most of horses often stopped grazing almost simultaneously soon after sunset and rested until midnight, and they devoted most of nighttime hours to resting in winter. It is summarized for Misaki horses that they graze actively at cool night in summer, and graze actively during warm daylight hours and rest at cold night in winter.

\section{Time spent grazing and resting in summer and winter:}

The extent to which animals can meet an increased food requirement will in part be determined by the availability of herbage and the ease with which it can be harvested ${ }^{2}$. Therefore, with an increase in food available, animals are able to spend more resting time. However, animals grazing on the pasture where food available is 


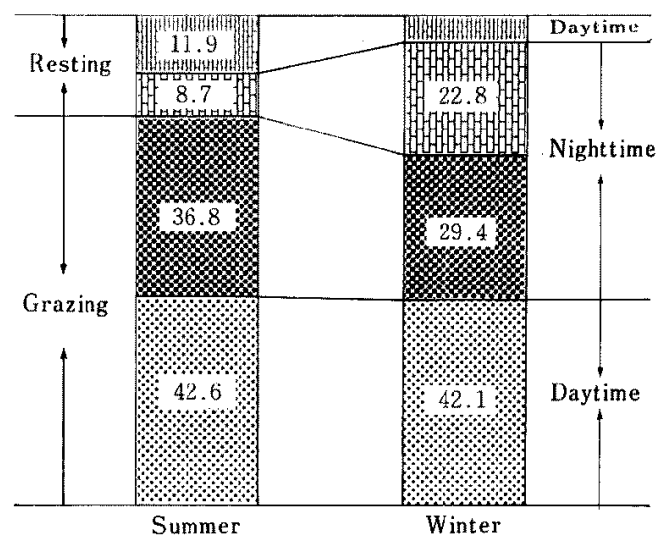

Fig. 4. Seasonal changes in the percentage of time spent grazing or resting in daytime and nighttime to the total time spent grazing and resting in the day.

poor must spend more grazing time ${ }^{2)}$. As shown in Fig. 1, total time spent grazing was longer in summer than in winter by 1.2 hours, but total time spent resting was inversely longer in winter than in summer by 1.8 hours. Seasonal changes in the proportion of time spent grazing or resting in daytime and nighttime is shown in Fig. 4. Time spent grazing in daytime was similar at approximately 10 hours in summer and winter, but time spent grazing at night was longer in summer than in winter by 1.5 hours, and time spent resting at night was contrarily longer in winter than in summer by 3.4 hours.

It has been reported that time spent grazing was greatly increased when animals grazed on a very poor pasture ${ }^{1-3,6}$. Range animals must expend more energy in seaching for and harvesting food and moreover, are obliged to expend more energy to maintain body temperature in cool temperature zone ${ }^{5,10)}$. Animals, therefore, must spend more grazing time to meet an increased food (energy) requirement on poor rangelands in winter. Horses in the present study, as mentioned above, were observed to spend less grazing time and more resting time in winter than in summer. The grasslands on which all horses grazed in summer were covered with Zoysia japonica, Imperata cylindrica and Cyperus rotundus etc, and food available were rich in quality and quantity. On the other hand, forests and weedy grasslands in which horses frequently grazed or brawsed in winter were covered with native grasses and forbs such as Miscanthus sinensis, Imperata cylihdcica and Cyclosorus acuminatus, and with trees available such as Machilus thunbergii, Mallotus japonicus and Ilex rotunda, which were much poor in quality and quantity. Therefore, horses were forced to consume not only leafless shoots but also fallen leaves in addition to grasses and forbs.

MALECHEK has observed that cows grazed less on cold than on warm days, nevertheless, they expended less energy on cold than on warm days. Then he has concluded that the net result of these alternations in behavioral patterns was a reduction 


\section{Grazing Patterns of Misaki Horses}

in energy expenditure for physical activities during period of weather stresses ${ }^{5}$. MOEN has reported in the study for deer that energy might be conserved by reducing the general level of activity, by seeking more level land and lesser snow depths and by walking more slowly'11.

Misaki horses, as previously mentioned, were frequently observed to graze actively within warm daylight hours and to stop grazing after sunset in winter. Throughout the cold night, most of horses frequently spent long resting bouts on the level sites in the forests. It is probable that resting in cold night may result in reduction of energy expenditure in winter.

The fact that Misaki horses spent less grazing time and more resting time in winter, therefore, suggested that they may achieve behavioral (and possibly physiological) adaptation to the environment in which food available is poor by reducing energy expenditure due to grazing or brawsing.

\section{References}

1) Hafez, E. S. E., Adaptation of Domestic Animals. 202-214. Lea \& Febiger. Philadelphia. 1968.

2) Arnold, G. W. and Dudzinski, M. L., Ethology of free-ranging domestic animals. 1-30. Elsevior. New York. 1978.

3) Tyler, S. J., Anim. Behav. Monogr., 5 85-196. 1972.

4) Cowan, R. T., Aust. J. Exp. Agric. Anim. Has., 15: 32-37. 1975.

5) MalecheK, J. C. and Smith, B. M., J. Range Manage., 29: 9-12. 1976.

6) Ellis, J. E. and Travis, M., J. appl. Ecol., 12: 411-420. 1975.

7) Salter, R. E. and Hudson, R. J., J. Range Manage., 32:221 225. 1979.

8) Berger, J., Behav. Ecol. Sociobiol., 2: 131-146. 1977.

9) Collery, L., Equine vet. J. , 6: 170-173. 1974.

10) Osun, P. O., J. Range Manage., 27: 437-443. 1974.

11) Moen, A. N., Ecology, 57: 192-198. 1976.

\section{御崎馬の採食時間乙休息時間の季節的变化}

加世田雄時朗

宮崎大学是学部，宮猞术 880

自然状態で周年放牧されている御崎馬 12 頭について, 1979 年 6 月加ら 1982 年 8 月 K, 55 回の $2 \sim 24$ 時間連繶 の行動観察を行い，採食時間と休息時間，気温及び採食 草樹種の季節的变化を調查して, 御崎馬の生息環境に対 する行動的適応について娭討した，夏は日中の暑い時は 休息をとることが多く，日没から梁夜にかけて最も活発 に採食した，一方冬は夜明けとともに採食を開始し，四 かい日中の大部分は探食に費やし休息は極めて少なか。 た。しかし気温が低下する夜は，日没とともに休息に入

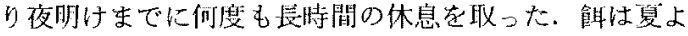

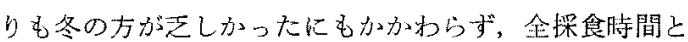

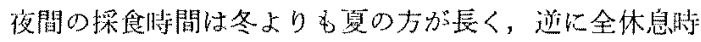
閒上夜間の休息洔間恃夏よりも冬の方が長かった。この 夏と冬の行動㤠の变化は，採食㭙間の短繀と休息時間の 延長によって採食行動で消耗するエネルギーを減らし， 飭のそしい冬の環境に刘して行動的に適応していること 定示ものと解釉さ机た。

日畜会報，54(7)：464-469，1983 